\title{
A KÖZIGAZGATÁS TÉRBELI VÁLTOZÁSAI AZ ALDUNAI-HEGYVIDÉK TÉRSÉGÉBEN A TÖRÖK HÓDOLTSÁGTÓL NAPJAINKIG
}

\author{
Elekes Tibor \\ egyetemi docens, Miskolci Egyetem, Földrajz-Geoinformatika Intézet \\ 3515 Miskolc, Miskolc-Egyetemváros, e-mail: ecoeti@uni-miskolc.hu \\ Szalóczy Gyula \\ végzett MSc hallgató, Miskolci Egyetem, Földrajz-Geoinformatika Intézet \\ 3515 Miskolc, Miskolc-Egyetemváros, e-mail: szaloczygy@gmail.com \\ Huszti Ádám Márk \\ végzett MSc hallgató, Miskolci Egyetem, Földrajz-Geoinformatika Intézet \\ 3515 Miskolc, Miskolc-Egyetemváros, e-mail: huadam94@hotmail.com

\section{Kémenes Hortenzia} \\ BSc hallgató, Miskolci Egyetem, Földrajz-Geoinformatika Intézet \\ 3515 Miskolc, Miskolc-Egyetemváros, e-mail: kemeneshortenzia98@gmail.com
}

\begin{abstract}
Absztrakt
A tanulmányozott területen a vármegye/megye, illetve az annak megfelelö kiterjedésü területegységek, rövidebb idöszakoktól eltekintve jelen vannak a térség utóbbi évezredének történelmében a Magyar Királyságban, a török hódoltság idején, a Habsburg időkben, a Monarchia Magyarországán és a 20-21. századi Romániában. A Habsburg idökben 1718-1779, 1784-1790 és 1849-1860 között a vármegyék feletti nagyobb közigazgatási egységeket alakitottak ki. 1950-1968 között müködtették Romániában a tartomány-rajon rendszert. A vármegyéknek, megyéknek alárendelt térszervezési szint, már a Habsburg birodalom idején létezett. 1950-ben számolták fel Romániában a járásokat. A közigazgatás legalsó szintjét a falu/község képezte. 1930-tól napjainkig Romániában az egy vagy több faluból álló komuna tölti be ezt a szerepkört. A térszervezés a természeti adottságok (domborzat, vizhálózat), a településhálózat, a társadalmi-gazdasági tényezök függvényében, de elsősorban a mindenkori politikai hatalom érdekei szerint alakult.
\end{abstract}

Kulcsszavak: Aldunai-hegyvidék, Krassó-Szörény, közigazgatás

\begin{abstract}
In the studied area, apart from shorter periods, the county and its corresponding territorial units are present in the history of the last millennium of the region in the Kingdom of Hungary, during the Turkish occupation, in the Habsburg times, in the Hungary of the Monarchy and in the 20th-21st centuries in Romania. In Habsburg times, between 1718-1779, 1784-1790 and 1849-1860, larger administrative units were formed over the counties. Between 1950 and 1968, the region-rayon/provinceldistrict system was operated in Romania. The level of spatial organization subordinate to the counties had already existed during the Habsburg Empire. In 1950, districts in Romania were abolished. The lowest level of public administration was the village. From 1930 to the present, in Romania, a commune consisting of one or more villages plays this role. The spatial organization developed according to the natural
\end{abstract}


conditions (topography, water network), the settlement network, socio-economic factors, but primarily according to the interests of the current political power.

Keywords: Alduna mountain, Caraș-Severin (Krassó-Szörény), public administration

\section{Bevezetés}

A történeti Temesi Bánságot (korábbi nevén Temesköz) a Duna, Tisza, Maros és a Déli-Kárpátokhoz tartozó Retyezát hegytömeg határolja. Keleti-délkeleti részét a Bánsági-hegyvidék alkotja, melynek déli részét képező Aldunai-hegyvidéket északon a Néra folyó által átszelt Almás-medence, keleten a Csernavölgye, délen az Aldunai-szoros határolja. Az 1224 m-es hegységet völgyek, medencék tagolják, szubmediterrán hatású éghajlat és élővilág jellemzi [1]. Lombhullató erdőinek kitermelése évszázadokkal korábban elkezdődött, a hagyományos gazdasági tevékenységek a fakitermelés, a szénégetés és a juh, illetve szarvasmarha tenyésztés.

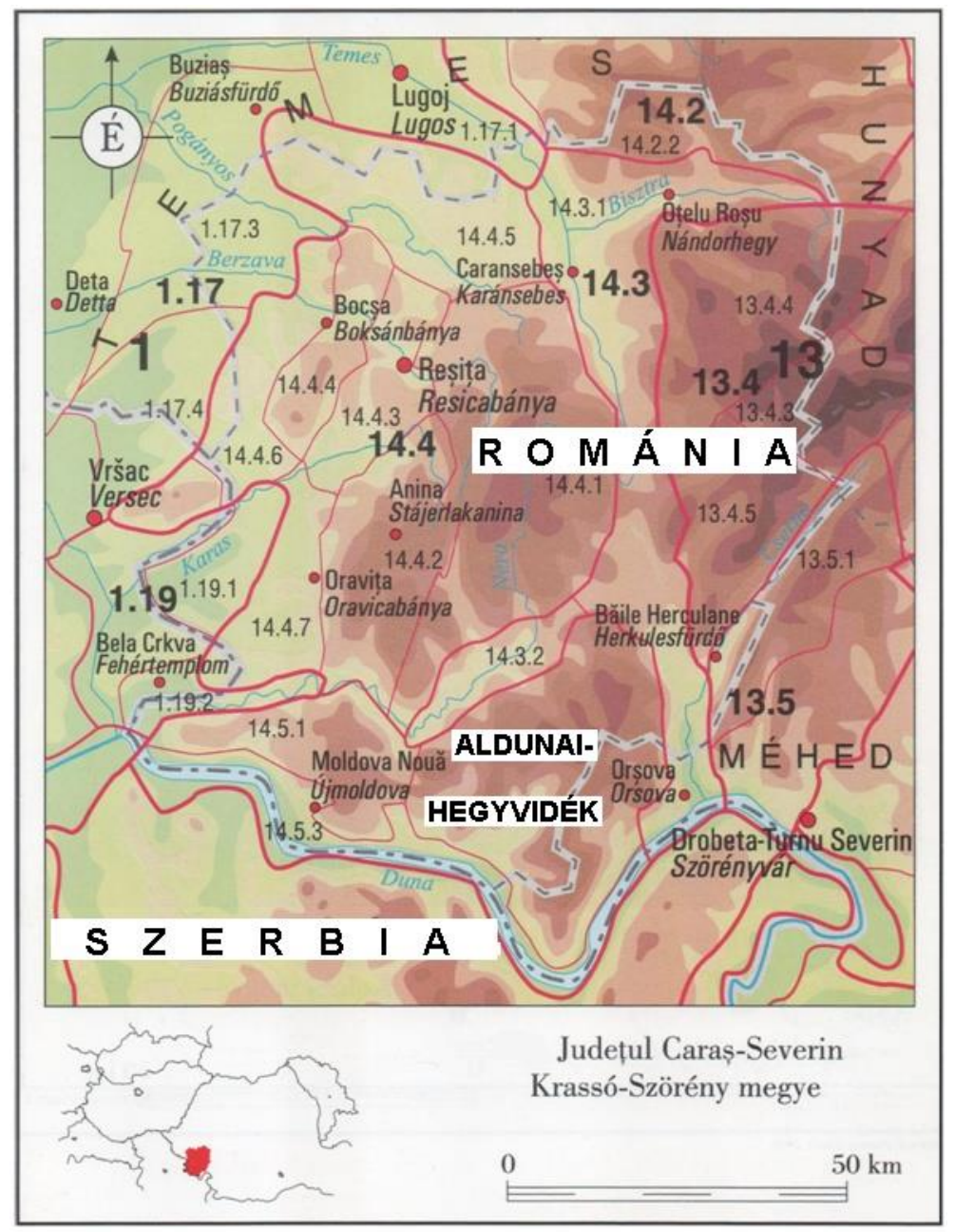

1. ábra. Az Aldunai-hegyvidék és térségének földrajzi helyzete (Forrás: Hajdú-Moharos J. 2000) 
Bányászatáról a 14-15. századi dokumentumok tanúskodnak [2]. Okiratok által említett településhálózatának kialakulása a 13. század elejéig nyúlik vissza. A legkorábban említett falu, a Temes folyó felső szakaszát az Aldunai határvidékkel összekötő közlekedési folyosó mentén települt Mehádia (Miháld, 1278). A 14. századtól említik az okiratok a Néra völgyének, a 15. századtól az Aldunai-szoros völgye bánsági részének falvait. A térség jelentősebb települései Orsova, Bozovics, Újmoldova, Berszászka, Teregova, a tágabb térségben Karánsebes régi közigazgatási központ. Az iparosodás, a bányászat felértékelődésével a tanulmányozott terület tágabb térségében jelentős gazdasági, társadalmi, közigazgatási szerepet kapott a mai Krassó-Szörény megyeszékhelye, Resicabánya, valamint Oravicabánya és Stájerlakanina. A turizmus Herkulesfürdő jelentőségét erősítette az Osztrák-Magyar Monarchia idejétől napjaikig [3-5]. Az Aldunai-szoros közelsége határmenti szerepet jelentett a térség számára [6-7] (1.ábra).

A Magyar Királyság idején, a török elleni harcok alatt, később a Habsburg időkben megritkult népességet telepesek pótolták. Az évszázadok során itt megtelepedett népcsoportok, nemzetiségek kialakították a Kárpát-medence egyik legváltozatosabb etnikai-felekezeti területét. A tanulmányozott terület a történeti Krassó és Szörény, a későbbi Krassó-Szörény délkeleti, keleti részében található. 1968-tól a tanulmányozott terület túlnyomó része továbbra is Krassó-Szörény megyéhez, délkeleti kisebb része a Drobeta-Turnu Severin (a régi Szörényvár) központú, Méhed (Mehedinţi) megyéhez tartozik [8].

\section{Célkitüzés, módszerek}

Az Aldunai-hegyvidék térségét a tágabb terület közigazgatás földrajzától részben eltérő, sajátos elemek, folyamatok jellemzik. Munkánk során elsősorban az évezrednyi történeti, közigazgatás földrajzi folyamaton belüli sajátosságokat összegeztük. Tanulmányoztuk a vonatkozó szakirodalmat, a hozzáférhető okiratok, település adatsorok segítségével összegeztük 11 időmetszetben a település szintủ térszervezés változásait. A kutatásaink során összegyüjtött adatokból a Photoshop CC, kisebb részt az ArcGIS 10.1 programok segítségével készítettük el a kartográfiai szintézist. Az elkészített térképek túlnyomó része korábbi publikációkban megjelent [9-18], jelen tanulmány a közigazgatási rendszer változásait, sajátosságait összegzi.

\section{Hét évszázad közigazgatása}

Szent István országába Ajtony veresége (1028) után integrálódott Bánság területén Csanád, illetve Gellért püspök vezetésével megkezdődött a királyi vármegyerendszer, illetve a latin rítusú egyházmegye kialakítása. Öt vármegyét létesítettek a térségben. Északon a Marostól északra is átterjedő Csanád és Arad, tőlük délre Temes, délnyugaton a Tisza és Duna által szegélyezett Keve, délkeleten a Dunáig és a Csernáig terjedő hegyvidéken Krassó vármegyét. A 11.-12. századi kun, bizánci, tatár betörések során a magyar, később a betelepített besenyő népesség pótlására kunokat, később szlávokat és németeket telepítettek a korabeli Temesi grófságnak nevezett területre. Zsigmond király idejében felértékelödött a Temesköz hadászati, stratégiai jelentősége. Az 1419-ben felépített Szörényi vár és az 1427-ben megszerzett Nándorfehérvár között a török betörések feltartoztatására az 1420-as években a Duna mentén 11 új vár épült (Szentlászlóvár, Galambóc stb.). Az országhatár védelmét Nándorfehérvár elestéig (1521), az Alduna-menti végvárak és részben a mögötte elhelyezkedő Temesköz látta el [2-4, 19, 20].

A Magyar Királyság világi és egyházi igazgatása öt évszázadon át létezett a Temesközben. A török hódoltság idején (1552-1718) a Csanád, Arad, Temes, Keve, Krassó és később Torontállal bővült területet a Temesvár központú, Temesvár, Becskerek, Csanád és Lippa szandzsákba osztott vilajetbe sorolták [21]. A másfél évszázad török megszállás a túlnyomórészt magyarok lakta terület pusztulását jelentette. Az elpusztult vagy elmenekült népesség helyére balkáni népcsoportok, törökök, szerbek, 
bunyevácok, görögök érkeztek. A 16. század közepi dokumentumok szerint nagyobbrészt szerbek és vlachok alkották a gyér népességü terület lakosságát. A Péterváradi győzelmet (1716) követően, a török hódoltságnak és közigazgatásnak a Pozsareváci béke (1718) vetett véget [20].

\section{A Habsburg idők katonai közigazgatása a Temesközben/Temesi Bánságban}

1718-ban III. Károly, a töröktől visszafoglalt, a Duna, Tisza, Maros és a Retyezát hegytömeg között elhelyezkedő Temesközt nem csatolta vissza Magyarországhoz, hanem Bécs által irányított katonai területként integrálta a Habsburg birodalomba. Az osztrák kormányszerveknek alárendelt, több korábbi vármegye területét magába foglaló Temesi Bánság koronatartomány továbbra is katonai szerepet töltött be. Stratégiai, gazdasági szerepének erősítését is szolgálta ebben az időszakban a nagyobbrészt római katolikus németek tömeges betelepítése, románok, szerbek betelepedése [22].

Több évtizedes közjogi viták, küzdelmek után 1778-ban a Temesi Bánság területén ismét lehetőség nyílt a magyar vármegye rendszer kialakítására. 1779-ben a Temesi Bánság területén újra létrehozták Temes vármegyét Temesvár székhellyel, Krassó vármegyét Lugos központtal, valamint a Nagybecskerek irányítása alá került Torontál vármegyét. A vármegyék településeit járásokba osztották. A településhálózat gerincét a megye-, illetve járásszékhely szerepkörrel ellátott jelentősebb városok, illetve e szerepkörök nélküli kisvárosok alkották. 1779-től a katonai kormányzás csak a Temesköz déli részén létrehozott Bánsági Határőrvidéken maradt fenn 1873-ig. A katonai célú „regionalizáció” jegyében létrehozott Németbánsági és Román-Illír határörezredek irányítását polgári ügyekben is a bécsi Udvari Haditanács intézte [3, 23]. Az általunk tanulmányozott terület túlnyomó része a Román-Illír határörezredhez tartozott. A határőrezred-határőrszázad-település katonai rendszer közel egy évszázadig meggátolta a térség integrációját, lassította gazdasági fejlődését.

II. József magyar király (1780-1790) a birodalom, és ezen belül Magyarország átszervezésére tett kísérletében a legnagyobb téregységet a több vármegyét magába foglaló kerületek képezték. A nagyfokú autonómiával rendelkező korábbi vármegyéket 1784-től 10 nagy magyarországi kerületbe, köztük a Temesvár székhelyü Bánságba ,integrálták”. II. József halála után visszaállt a korábbi térszervezés [3, 20].

1845 után a Román-Illír határőrezred kettévált. Keleti részén létrejött a Románbánsági (más néven Oláh bánsági), nyugati felén pedig a Szerbbánsági (más néven Illír bánsági) ezred, gyakran változó ezred és századhatárokkal. A határőrezred-határőrszázad-település rendszerben 1845 után a Románbánsági ezred századai: a Mehádiai- 7, az Orsovai- 12 (?), a Berszászkai- 7, a Dalboseci- 4, a Bozovicsi- 3, a Prigori- 5, a Petneki- 6, a Korniai (Somfai)-század 4 beosztott faluval [5, 24].

Az 1848-1849-es forradalom leverése után Ferenc József neoabszolutista kormányzatot vezetett be, tovább folytatódott Magyarország megmaradt területének közigazgatási széttagolása, a katonai közigazgatás bővítése, erősítése [5, 25]. 1849 végén a Bach-korszak szellemében Bács-Bodrog, Temes, Krassó, és Torontál, valamint Szerém megye két járásából megalakították a német közigazgatási nyelvü Szerb Vajdaság és Temesi Bánság koronatartományt. Az új területegység körzetei 1849-1850 között: BácsTorontál, Szerémség és Temesvár-Krassó. Ekkor az általunk tanulmányozott terület az utóbbihoz tartozott. Az 1850-1860 között müködtetett 5 körzet központjai: Nagybecskerek, Újvidék, Zombor, Lugos és Temesvár. A forradalom után kialakított katonai közigazgatási egységeket 1860-ban számolták fel és 1861 januárjától a korábbi térfelosztás müködött. Az Aldunai-hegyvidék térségében ismét érvényesült a korábbi vármegyék és 1873-ig a Katonai Határörvidék térszervezése [3-5].

A Török birodalom fokozatos gyengülésével leértékelődött a Habsburg birodalom déli részén kialakított Katonai Határörvidék jelentősége. Az osztrák-magyar kiegyezést követően a korábbi katonai területek fokozatosan integrálódtak a polgári közigazgatásba. 1873-ban a határőrvidék újra a magyar 
állam részévé vált. A korábbi határőrök állandó katonai szolgálata helyett érvényesítették a polgári lakosság általános hadkötelezettségét [3, 20, 23].

\section{Vármegyék, megyék rendszerei 1873-1950 között}

1873-ban véglegesen felszámolták a Katonai határőrvidéket. Területének túlnyomó részét Torontál, kisebb részét Temes és Krassó megyékhez osztották. A Románbánsági ezred településeiből és a Szerbbánsági ezred egy részéből 1874-ben létrehoztak egy önálló törvényhatóságú egységet, a Karánsebes központú, kis területü Szörény megyét. A korábbi katonai századok falvait járásokba sorolták $[3,5]$.

Az osztrák-magyar kiegyezést követően (1867), 1876-ben vezették be Magyarországon a polgári közigazgatást [30, 31]. Az új térfelosztás felszámolta a történelmi Magyarország területén évszáza-dokon át müködött kiváltságos területeket (székek, vidékek), ugyanakkor az új vármegyék területét jelentős mértékben a hagyományos térszerkezet, kiterjedés, etnikai-felekezeti sajátosságok függvényében alakították ki. A székhellyel rendelkező vármegyéket a járásokba osztott városok, nagy- és kisközségek hálózata alkotta. Átértékelődött a korábbi szabad királyi városok és mezővárosok szerepköre. A jelentősebb gazdasági-társadalmi potenciállal rendelkezők törvényhatósági jogú városok lettek, a megyével egyenrangú egységként a megye székhelyeként müködtek. A kevésbé sikeres városok a rendezett tanácsú városok közé sorolódtak, a megyeközpontnak alárendelt, de a járással egyenrangú, és a járást irányító központként tevékenykedtek. A kisebb mezővárosok elveszítették korábbi városi címüket és a nagyobb falvakkal a nagyközségek csoportjába kerültek. A kisebb falvak a kisközségek szintjén szerveződtek. A törvényhatósági jogú városok, megye- és járásszékhelyként is müködhettek, így több egymás alá rendelt közigazgatási szerepkört is betöltöttek [4, 8].

1880-ban Lugos központtal, Krassó-Szörény vármegye néven egyesítették az addig önálló Krassó és Szörény vármegyét [32]. A $11074 \mathrm{~km}^{2}$ kiterjedésủ terület Magyarország második legnagyobb vármegyéje volt, az általunk tanulmányozott terület településeit az Orsovai, Újmoldovai, Bozovicsi, Jámi és Teregovai járásba osztották. 1913-ban a megyéhez csatolták a már 1878-ban megszállt, de addig az Oszmán Birodalomhoz tartozó, török lakosságú, 1970-ben a Vaskapui vízerőmü építésével elárasztott dunai szigetet, Ada-Kaleht $[3,5]$.

Az I. világháború után Magyarországtól Romániához került 103093 km² magába foglalta a Bánság északkeleti részét Krassó-Szörény megyével együtt. Az új, román nyelvü közigazgatás 1925-ig nem változtatott a térség korábbi térfelosztásán [26]. A megyék járásaiban egy-egy település alkotott egy városi, vagy falusi komunát. Az Ó-romániai és a háború alatt, illetve után megszerzett területek közigazgatási egységesítésére 1925-ben került sor [32]. Az átszervezés után is megmaradt a megye-járásvárosi/falusi komuna rendszer. A tanulmányozott terület viszonylatában a legjelentősebb változást az 1880-ban egyesített Krassó-Szörény megye újbóli kettéválasztása jelentette, jelentős mértékben átrajzolt járásokkal. 1925-ben városi címet kapott a tanulmányozott terület legjelentősebb települése, Orsova [5, 26].

1930-ban a korabeli Nagy-Románia területét részben a történelmi régiókhoz igazodó 7 tartományra osztották. A megyék fölé rendelt tartományokat a fővárosban kinevezett minisztériumi igazgatóságok irányították. Nem változott a tartományoknak alárendelt megyék kiterjedése, de változott a járásbeosztás. Ekkor a közigazgatás legalsó területi szintjét az 1 vagy több falut magába foglaló komunák alkották. Az 1930-ban létrehozott Bánsági tartomány része volt Krassó és Szörény megye. A központi irányítás további erősödését szolgálta az 1938-ban létrehozott 10 új tartomány. Krassó és Szörény megyét a Temesvár központú Temes tartományhoz sorolták [26, 27, 34, 35].

1940-ben Besszarábia, Észak-Bukovina, Dél-Dobrudzsa és Észak-Erdély elvesztése után a megyék szintjén szervezték újra a jelentősen megváltozott romániai országterületet. 


\section{Tartomány-rajon és megyerendszer 1950-től napjainkig}

A II. világháború utáni szocialista államokban a közigazgatásban is érvényesült a kor uralkodó ideológiája. A gazdasági-társadalmi fejlesztés és az új térszemlélet alapján, 1950-ben Romániában a szovjet oblaszty-rajon mintájára bevezették a diktatórikus államhatalom által irányított tartomány-rajon rendszert. A térfelosztás legmagasabb szintjét képező tartományokat a korábbi megyéknél kisebb, a járásoknál nagyobb rajonok alkották. A városokat három eltérő közigazgatási funkciójú csoportba sorolták: köztársasági, tartományi és rajoni alárendeltségüek. A legkisebb közigazgatási egység az egy vagy több faluból álló komunák szintjén szerveződött [26-28].

1950-1952 között Szörény tartományhoz sorolódott az általunk tanulmányozott terület. A rajonokat korábbi járások összevonásával, átrajzolásával alakították ki. Az 1952-es átszervezés után Szörény valamint Temesvár középső és déli része alkotta az új Temesvár tartományt. 1956-ban a korábbi Arad déli részével bővítették Temesvár tartomány területét. Az 1952-es és 1956-os átszervezések során jelentősen változott a rajonok kiterjedése. 1960-ban az 1956-ban kialakított Temesvár tartományt átnevezték Bánságra, keveset módosult a rajonok kiterjedése [28, 29, 36-39].

A „Sztálini-korszak” utáni enyhülés idején erősödött a nemzeti jelleg a politikai, társadalmi életben. A román államépítést szolgálta az 1968-ban kialakított megyebeosztás [40]. Az új megyék létrehozásánál gyakran mellőzték a hagyományos térszerveződést, a földrajzi adottságokat, az etnikai, felekezeti szempontokat. Az 1876-ban létrehozott Orsovai járás déli részét Orsova várossal és a Kazán-szoros térségével 1968-tól a Turnu-Severin (a régi Szörényvár) központú, dél-Romániai Méhed (Mehedinţi) megyéhez csatolták. A tanulmányozott terület túlnyomó része továbbra is Krassó-Szörény megyé déli részét alkotja [29, 40]. A megyén belüli közigazgatás alsó szintjét a megyeszékhely funkció nélküli városok és az egy vagy több faluból álló komunák képezték. A jelentősebb városokat municípiumi (megyei jogú város) rangra emelték. Napjainkban 3 csoportba sorolják a municípiumokat: „0”rang: Bukarest, „I”-rang: 11 nagyváros, „II” rang: a további 101 municípium.

\section{7. Összefoglalás}

Az Aldunai-szoros térsége országokat, birodalmakat elválasztó határ menti területként ismert. 1028 után a Temesközben megszervezett világi közigazgatás keretében hozták létre Csanád, Arad, Temes, Keve, Krassó és később Torontál vármegyéket. A vármegye/megye, illetve az annak megfelelő kiterjedésü területegységek térszervezési szintje, rövidebb időszakoktól eltekintve végig kiséri a térség utóbbi évezredének történelmét (2.ábra). A török hódoltság idején (1552-1718) a vármegyék területéhez hasonló kiterjedésủ szandzsákok fölött egy polgári és katonai vezető által irányított, „tartományi méretü” vilajet állt. A Temesvár központú vilajethez tartozott 4 szandzsák: Temesvár, Becskerek, Csanád és Lippa. 1718 után a Habsburg birodalomhoz csatolt Temesköz területén létrehozták a bécsi katonai irányítású Temesi Bánság koronatartományt. 1779-től a Temesi Bánság északi és középső részén újra bevezették a polgári közigazgatást, a vármegyék rendszerét (Temes, Krassó és Torontál). A katonai közigazgatás a Temesköz déli részén létrehozott Bánsági Határőrvidéken maradt fenn 1873-ig. Ezt követően ez a terület is integrálódott a vármegyerendszerbe. A Habsburg időkben két rövid idejü, a vármegyék feletti nagyobb területegységet létrehozó átszervezésre került sor. 1784-1790 között a több vármegye területét magába foglaló kerületek (Temesvár székhelyü Bánság) szintjén szervezték meg a térfelosztást. 18491860 között a vármegyékhez hasonló méretü kerületek fölé szervezték a Szerb Vajdaság és Temesi Bánság koronatartományt. 

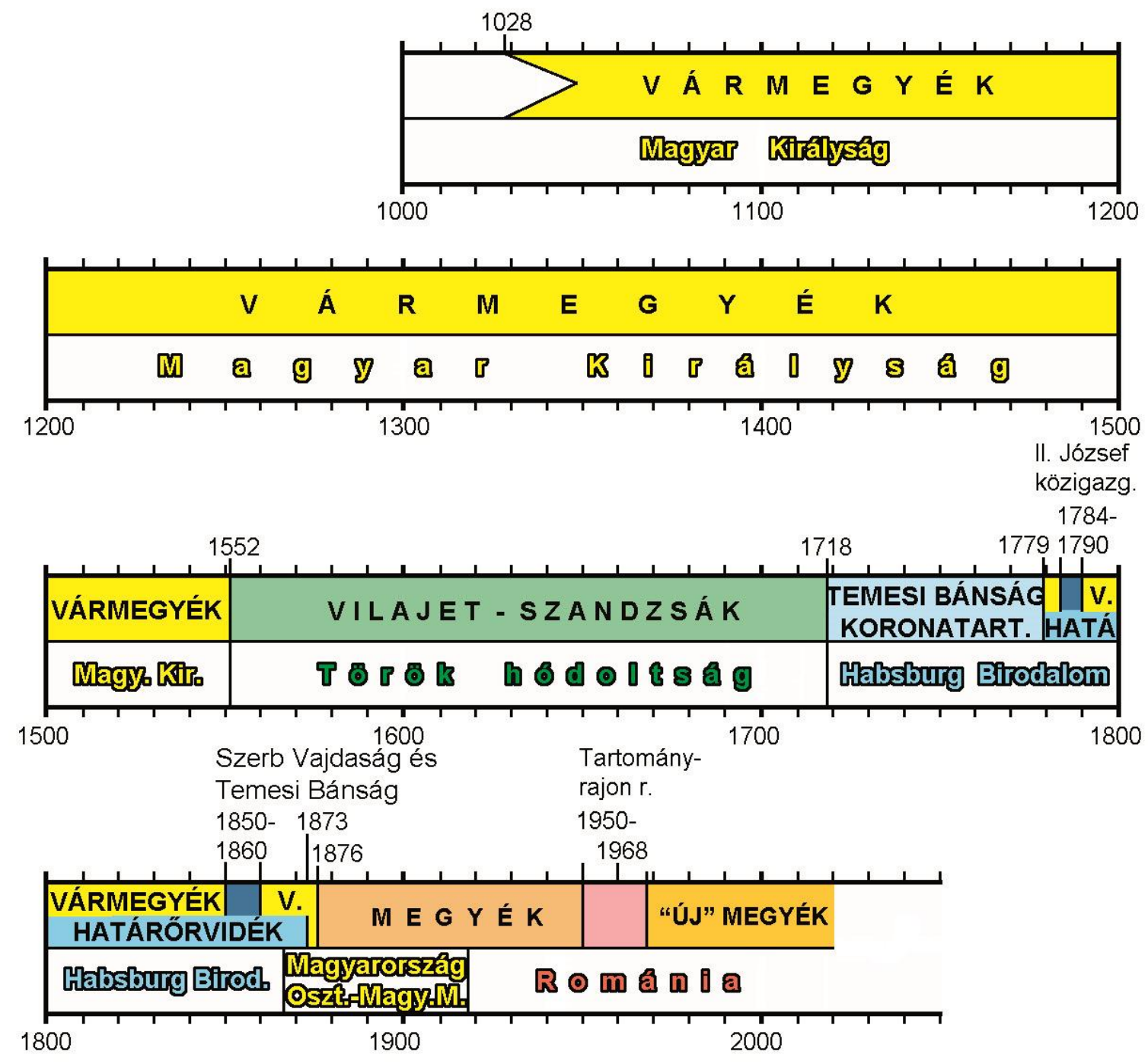

2. ábra. Az Aldunai-hegyvidék térségének közigazgatási rendszerei.

A vármegyéknek, megyéknek alárendelt térszervezési szint, a járás bizonyíthatóan létezett a tanulmányozott terület viszonylatában már a Habsburg birodalom idején. 1873 után a Temesi Bánság (Temesköz) teljes egésze a vármegyei közigazgatás alá került. 1873-1919 között többször alkalmaztak kisebb változtatásokat a korabeli Magyarország ezen térségének megye és járásbeosztásában. A tanulmányozott terület járási szintü térszervező központjai Orsova, Bozovics, Szászka és Újmoldova. Az 1919-ben berendezkedő új román hatalom 1925-ig megtartotta a térség háború előtti Krassó-Szörény megyébe szervezett felosztását. 1926-1950 között többször változtatták a megyék és járások területét, majd 1950től felszámolták a járások közigazgatási szintjét Romániában.

Évszázadok során, a gyakran vármegye-, szék-, vidék-, valamint járásközponti szerepkört is ellátó szabad királyi városok-mezővárosok rendszerét az 1876-os polgári közigazgatás szabályozta. 
Létrehozták a törvényhatóságú, illetve rendezett tanácsú városokat. 1925 után Romániában a városi komuna fogalmát használták, 1950-1968 között a városokat köztársasági, tartományi, rajoni alárendeltségü csoportokba sorolták. 1968-tól a megyeszékhelyek és a jelentősebb romániai városok a municípium (megyei jogú város) címet viselik.

A közigazgatás legalsó szintjét a falu/község képezte, 1930-tól napjainkig Romániában az egy vagy több faluból álló komuna tölti be ezt a szerepkört.

Összességében megállapítható, hogy a térszervezés a természeti adottságok (domborzat, vízhálózat), a településhálózat, a társadalmi-gazdasági tényezők függvényében, de elsősorban a mindenkori politikai hatalom érdekei szerint alakult. A hagyományos térfelosztást az aktuális államhatalom érdekei függvényében, a nagy történelmi fordulópontokat követő időszakokban változtatták.

\section{Köszönetnyilvánítás}

A cikkben ismertetett kutató munka az EFOP-3.6.1-16-2016-00011 jelü „Fiatalodó és Megújuló Egyetem - Innovatív Tudásváros - a Miskolci Egyetem intelligens szakosodást szolgáló intézményi fejlesztése" projekt részeként - a Széchenyi 2020 keretében - az Európai Unió támogatásával, az Európai Szociális Alap társfinanszírozásával valósul meg.

\section{Irodalom}

[1] Kocsis, K. (föszerk.): Magyarország Nemzeti atlasza. Természeti környezet. MTA Csillagászati és Földtudományi Kutatóközpont, Földrajz Intézet, Budapest 2018, 167 p

[2] Pesty, F.: A szörényi bánság és Szörény vármegye története. I-III. Magyar Tudományos Akadémia Könyvkiadó Hivatala, Budapest, 1877-1878, 482p, 579p, 426p.

[3] Kókai, S.: A Bánság történeti földrajza (1718-1918). Nyíregyházi Főiskola Turizmus és Földrajztudományi Intézete, Nyíregyháza, 2010, 421p.

[4] Hajdú, Z.: A Bánság térfejlődésének közigazgatás-történeti csomópontjai 1918-ig. In: Gulyás L. (főszerk.): Közép-Európai Közlemények 3. évf. 2. sz., Egyesület Közép-Európa Kutatására, Szeged, 2010, pp. 7-16.

[5] Szabó, M. A.: Erdély, Bánság és Partium történeti és közigazgatási helységnévtára. Pro-Print Könyvkiadó Csíkszereda, 2003 https://www.arcanum.hu/hu/online-kiadvanyok/ErdelyHelysegnevTar-erdely-bansag-es-partium-torteneti-es-kozigazgatasi-helysegnevtara-1/ (2018.02.10)

[6] Suba, J.: Határörvidék - határvédelem a földrajzi térben. In: Gulyás L. (föszerk.): A Virtuális Intézet Közép-Európa Kutatására közleményei, 1. évf. 1. sz., Szeged, 2009, pp. 255-260.

[7] Hajdú-Moharos, J.: Magyar településtár. Kárpát-Pannon Kiadó, Budapest, 2000, 788 p.

[8] Gyalay, M.: Magyar igazgatástörténeti helységnévlexikon. Budapest, 1989.

[9] Huszti, Á. M., Elekes, T.: Krassó-Szörény megye keleti részének közigazgatása 1779-1876 között. Müszaki Földtudományi Közlemények, 89.: 1. 2020, pp. 131-138.

[10] Huszti, Á. M., Elekes, T.: Krassó-Szörény megye keleti részének közigazgatása 1876-1925 között. Müszaki Földtudományi Közlemények 89. 1. 2020, pp. 139-144.

[11] Huszti, Á. M., Kémenes, H.: Krassó-Szörény megye keleti részének közigazgatása 1925-1941 között. Múszaki Földtudományi Közlemények (megjelenés alatt).

[12] Huszti, Á. M., Elekes, T.: Tartomány-rajon rendszer Krassó-Szörény keleti részében 1950-1968 között. Müszaki Földtudományi Közlemények (megjelenés alatt)

[13] Szalóczy, Gy., Elekes, T.: Osztrák katonai közigazgatás az Aldunai-hegyvidék térségében 17181873 között. Müszaki Földtudományi Közlemények 89. 1. 2020, pp. 9-19. 
[14] Szalóczy, Gy., Elekes, T., Szalontai, L.: Az Aldunai-hegyvidék térségének közigazgatása 18731925 között. Müszaki Földtudományi Közlemények 89. 1. 2020, pp. 20-28.

[15] Szalóczy, Gy., Elekes, T: Közigazgatási változások az Aldunai-hegyvidék térségében 1925-1950 között. Müszaki Földtudományi Közlemények (megjelenés alatt).

[16] Szalóczy, Gy., Elekes, T: A tartomány-rajon rendszer az Aldunai-hegyvidék térségében 19501968 között. Müszaki Földtudományi Közlemények (megjelenés alatt).

[17] Elekes, T., Szilágyi, F.: Administrative, spatial and demographic changes in Székelyland since the Treaty of Trianon to the present day. Regional Statistics 10: 1, 2020, pp. 120-132.

[18] Szilágyi, F., Elekes, T.: Changes in administration, spatial structure, and demography in the Partium region since the Treaty of Trianon. Regional Statistics 10: 1, 2020, pp.101-119

[19] Szilágyi, F.: Partium társadalom és térszerkezet. Dokumentum kiadó, Nagyvárad, 2013, 306 p.

[20] Köpeczi, B. (szerk.): Erdély rövid története. Akadémiai Kiadó, Budapest, 1993, 684 p.

[21] Engel, P.: A temesvári és moldovai szandzsák törökkori települései, 1554-1579. Csongrád Megyei Levéltár, Officina Nyomda, Szeged, 1996, 190p.

[22] Gyémánt, R.: A Bánság újratelepitése, különös tekintettel a 18. századi telepitési folyamatokra. In: Homoki-Nagy M. (föszerk.): Acta Universitatis Szegediensis: forum: acta juridica et politica, 5. évf. 1. sz., Szeged, 2015, pp. 31-48.

[23] Diós, I., Viczián J.: Magyar Katolikus Lexikon I., VII., XIII. Szent István Társulat, Budapest, 2008, 948p, 926p, 1000p.

[24] Vistai, A. J.: Tekintő. Erdélyi helynévkönyv, 1-3. kötet (adattári tallózásból összehozva). [Hely és év nélkül, csak a világhálón közzétéve.] Online hozzáférés: https://web.archive.org/web/20110710231100/ http://www.fatornyosfalunk.com/html/erdelyi_helynevkonyv.html

[25] Elekes, T., Gyenizse P.: A földrajzi tényezők és a közigazgatás kapcsolatrendszere Erdélyben. Észak-Magyarországi Stratégiai Füzetek. 2: 2, 2014, pp. 118-126.

[26] Bucur, C. (2012): Organizarea administrativ-teritorială a României între tradiţie istorică, dictat politic, sincronism european, decizie administrativă şi analiză ştiinţifică. Urbanismul serie nouă 11. pp. 50-56.

[27] Bajtalan, H.: A regionalizáció folyamata Romániában: 1859-2013. Erdélyi Társadalom 11(2) pp. 67-83. 2013: http://www. erdelyitarsadalom.ro/files/et22/et-bbu-22-04.pdf

[28] Elekes, T.: Demográfiai, gazdasági-társadalmi folyamatok Románia városaiban 1948-tól napjainkig. Tér és Társadalom 22: 2, 2008, pp.183-201. https://doi.org/10.17649/TET.22.2.1177

[29] Bereznay, A.: Erdély történetének atlasza. Méry Ratio Kiadó, 2011, 223p.

[30] 1876. évi XXXIII. törvénycikk némely törvényhatóság területének szabályozásáról és az ezzel kapcsolatos intézkedésekröl

[31] 1877. évi I. törvénycikk némely törvényhatóságok véglegesen megállapított területének az 1876. évi XXXIII. tc. rendelkezése folytán törvénybe iktatásáról

[32] 1880. évi LV. törvénycikk.

[33] Legea No. 95 pentru Unificarea Administrativă din 12 iunie 1925. In Ministerul Justiţiei Colecţiune de Legi şi Regulamente (1 ian. 1925-31 dec. 1925) Tomul III. 1925, Bucureşti.

[34] Legea pentru organizarea administraţiunii locale din 3 august 1929, Bucureşti.

[35] Decret-Lege Nr.347. leg. Administrativă din 14. August 1938. In Monitorul Oficial Nr. 187 din 14. aug.1938.

[36] Legea Nr.5. privind noua împărţire administrativ-economică a ţării în regiuni şi raioane. In Buletinul Oficial Nr.77 din sept. 1950, Bucureşti. 
[37] Decret 331/27.sept. 1952 privind modificarea Legii 5 din 1950 pentru raionarea administrativeconomică a României, Bucureşti.

[38] Decretul 121956 pentru raionarea administrativ-economică a României, Bucureşti.

[39] Împărţirea administrativă a teritoriului Republica Populare Romîne.1960, Anexa la Leg. Nr. 3/1960. Bucureşti

[40] Lege pentru modificarea legii Nr.2/1968 privind organizarea administrativă a teritoriului Republicii Socialiste România. Buletinul Oficial, 1968, Bucureşti. 